\title{
Chemical and mechanical methods on fruit setting and pomological traits of Chinese jujube (Ziziphus jujuba Mill.) under Czech agro climatic condition
}

\author{
S. Mishra ${ }^{1 匹}$, M. Tarafdar ${ }^{1}$, R. K. Singh ${ }^{1}$ \\ ${ }^{1}$ Department of Horticulture, Faculty of Agriculture, Sam Higginbottom University of Agriculture, \\ Technology and Sciences, Allahabad, India \\ E-mail: mishrasaket1@gmail.com
}

\begin{abstract}
The aim of this research was conducted to improve fruit set using different types of treatments and to find out the best treatment on the basis of number of fruits and pomological traits. For the research, ten years old 12 Lang cultivar of jujube trees and 3 seedlings from open pollinated of Ukraine genotypes were used. The tree spacing was 3.50×1.26 m. Spraying of Borax showed that average numbers of fruits were higher than the other treatments, average values of height, weight, width and thickness were also higher than the other treatments. On the other hand Urea and Girdling gave poor results in both years. In case of seedlings, different treatments for fruit setting have not given good results. Spraying with different treatments did not affect fruit-setting and pomological characteristics as well, in a larger scale. In 2006 , bud breaking started in jujube cultivars on $28^{\text {th }}$ April and in seedlings on $6^{\text {th }}$ May. In 2007, bud breaking started in jujube cultivars 11 days earlier and 10 days earlier on $26^{\text {th }}$ April in seedling. In jujube cultivars, there were some variations in the dates of flowering during 2006; the average date of flowering was $26^{\text {th }}$ June in 2006 for all cultivars of jujube. In seedlings, flowering started on $6^{\text {th }}$ July 2006. During 2007 flowering started in jujube cultivar jujube cultivars started flowering 12 days earlier and seedlings 22 days earlier. During 2006, fruit set started in jujube cultivars and seedlings, on $12^{\text {th }}$ July and $14^{\text {th }}$ July respectively. During 2007 , fruit set started in jujube cultivars and seedlings on $1^{\text {st }}$ July and $10^{\text {th }}$ July respectively. In 2007 fruit set in jujube cultivars started 11 days earlier and in seedlings 4 days earlier. During 2006, ripening started in jujube cultivars and seedlings on $26^{\text {th }}$ Sept. During 2007 ripening started in jujube cultivars and seedlings on $2^{\text {nd }}$ and $10^{\text {th }}$ Sep. respectively. In 2007, ripening started in jujube cultivars 24 days earlier and seedlings 16 days earlier. Statistical evaluations of the data showed the differences between 2006 and 2007.

Keywords: jujube, cultivars, seedlings, flowering, fruit setting, timing.
\end{abstract}

For citation: Mishra S., Tarafdar M., Singh R. K. Chemical and mechanical methods on fruit setting and pomological traits of Chinese jujube (Ziziphus jujuba Mill.) under Czech agro climatic condition // Agrarian Bulletin of the Urals. 2020. No. 06 (197). Pp. 17-25. DOI: ...

Paper submitted: 25.05.2020.

\section{Introduction}

Chinese jujube (Ziziphus jujuba Mill.) is a deciduous fruit tree having Rahamanaceae family that ripens its fruit in autumn. It is grown in the temperate and subtropical areas of the Northern Hemisphere, especially the drier parts of north China. Chinese jujube appears to be principally diploid $(2 n=2 x=24)$, although some polyploidy plants have been propagated as cultivars, whereas Indian jujube is tetraploid $(2 n=2 x=48)$. As it is a plant well adapted to the climate in this region, lasts for long time, and fits in long-term intercropping systems; Chinese jujube has become more popular in different parts of China, especially in the dry northern parts. It is considered to be an ideal economic crop for arid and semiarid areas where common fruit trees do not grow well [12]. Accordingly, the International Centre for Underutilized Crops in Southampton, U. K., identified Chinese jujube as a crop with substantial growth potential in 2006 [1]. Recently, its cultivation has witnessed an increase in other regions in the world such as the southwest Europe, the Middle East, and India. The fruit of Chinese jujube is rich in nutritive substances and has high medicinal value. Beside fresh consumption of the pulp, it can be dried or processed to be used in confectionary recipes in bread, cakes, and candy [9]. In addition to it nutritional usages, Chinese jujubes have been used as a traditional medicine [13]. In particular, the seeds are known for their sedative effect [10], which has been connected to the flavonoids available in the seeds. Consequently, products of Chinese jujube are being distributed as functional food, which In the United States, are available at health food stores [17]. Since FAO stat does not maintain statistics on this crop, it was referred to the Agris, Agricola and CABI tabloid data base to have insight of the statistical aspects of the Chinese jujube and related research in literature [14]. It was found that China and Korea were the two leading countries in the research on Chinese jujube. According to the China Agricultural Yearbook, China is the largest producer whose production has increased by $16 \%$ annually since 2003 and reached approximately 7.4 million tons in 2013 . Beside China, the crop is grown commercially mainly in Korea 
whose growing area is $4676 \mathrm{ha}$, while the annual production is 20 thousand tons approximately [1]. Smaller areas of production can be found scattered in the dry regions of Thailand [14], France [17], Italy [3]. In other countries, if Chinese jujube are found, they would be used mainly for germplasm research or ornamental purposes [12]. Cultural practice of the Chinese jujube farming depends mainly on hand labor [15]. Particularly, the shortage of labor in required during the limited harvesting season leads to an in- crease in labor cost, which is one of the major problems facing farmers [2]. In fact, this labor intensive harvesting practice have become increasingly serious that it may threaten the stability of its cultivation and weaken the international competitiveness of the Chinese jujube industry.

It is worth mentioning that for intensive planting, some engineering technologies have been already employed to save labor and improve production. For example, digging machines are used for tree transplanting [11]; and branch pruning tools are utilized to control the number, length and opening of branches to improve lighting conditions and increase leaf area index [5]. One example of these tools is a knife designed specifically for jujube branch pruning after studying the mechanical properties of the branch [4]. At the same time, researches to fully automate pruning are ongoing [5].

Ecology and Climatic Requirements

Chinese jujube is a deciduous fruit tree, typically possessing thorny branches. Their leaves are ovate-acute, with three conspicuous veins at the base and finely toothed margins. They can withstand extreme arid conditions and produce reasonable yields. Many famous Chinese jujube cultivars are cultivated in Northwest China, which is well known for its arid climate.
In Northwest China, the annual precipitation is usually below $200 \mathrm{~mm}$ in arid, 200-450 $\mathrm{mm}$ in semi-arid, and 450-650 $\mathrm{mm}$ in sub-humid regions. Jujube can grow and thrive in a wide range of temperatures. Usually it could tolerate cold winters and survive temperatures as low as $-20^{\circ} \mathrm{C}$. This enables jujube to grow in mountains or deserts, and in cold regions. In addition, under different climatic conditions, jujube cultivars are diverse for traits, such as fruit shape, flavor, color, botany traits, and propagation ability [11]. Most species of Ziziphus can be found in low rainfall areas. The climatic and ecological background to the three important cultivated species is shown in the table [16]. Ecological requirements of the main jujube species are given in the table 1.

\section{Reproductive Biology}

The small flowers are produced in great abundance in spring and early summer. Although the flowers are perfect, the plants come in two mating types-one in which flowers open in the morning and the second in which flowers open in the afternoon. Most or all plants appear to be self - incompatible, but some cultivars are capable of setting large crop of fruit when planted in isolation. The stones of these when opened, seldom contain viable seeds. Some cultivars, even when planted among many other clones for cross - pollination, produce only seedless fruit, although stones are present. Some cultivars produce little or no fruit without cross pollination. The flowers are very fragrant and attract numerous insects of many species. Each stone potentially contains two seeds. The plant's flower relatively late in the spring and the fruit require 2-5 months to mature. If squirrels and crows are abundant, they can remove much of the fruit before it ripens [7].

Table 1

Ecological requirement of the main jujube species

\begin{tabular}{|l|l|l|l|}
\hline & \multicolumn{1}{|c|}{ Z. mauritiana } & \multicolumn{1}{c|}{ Z. jujube } & Z spina chhristi \\
\hline Latitude & $30^{\circ} \mathrm{N}$ to $30^{\circ} \mathrm{S}$ & $300 \mathrm{C}$ to $510 \mathrm{~N}$ & 00 to $200 \mathrm{~N}$ \\
\hline Altitude (m) & $<1500$ & Up to 2800 & $<1000$ \\
\hline Eco region & Warm Lowland plains & Cool highlands & Mediterranean dry lands \\
\hline Minimum temperature & 4 to $12^{\circ} \mathrm{C}$ & -100 to $200{ }^{\circ} \mathrm{C}$ & -5 to $20^{\circ} \mathrm{C}$ \\
\hline Maximum temperature & 39 to $45^{\circ} \mathrm{C}$ & $360^{\circ} \mathrm{C}$ & $50^{\circ} \mathrm{C}$ \\
\hline Rainfall $(\mathrm{mm})$ & $>300$ & 200 to 450 & $\mathrm{Ca} 100$ \\
\hline Soil type & Shallow to deep and soil & Alluvial plains hills & Poor soils of arid areas \\
\hline Alkalinity & $<45 \mathrm{ESP}$ & Highly tolerant & Some tolerance \\
\hline
\end{tabular}

Table 2

Climatic characteristics of warm region T4 [19, Pp. 232-233]

\begin{tabular}{|l|c|}
\hline \multicolumn{1}{|c|}{ Parameters } & Climatic characters of warm region T4 \\
\hline Number of summer days & $60-70$ \\
\hline Number of days with mean temperature $>100{ }^{\circ} \mathrm{C}$ & $170-180$ \\
\hline Number of days with frost & $100-110$ \\
\hline Number of ice days & $30-40$ \\
\hline Mean January temperature & $-2 \ldots-3{ }^{\circ} \mathrm{C}$ \\
\hline Mean July temperature & $19-20{ }^{\circ} \mathrm{C}$ \\
\hline Mean April temperature & $9-10^{\circ} \mathrm{C}$ \\
\hline Mean October temperature & $9-10{ }^{\circ} \mathrm{C}$ \\
\hline Mean number of days with precipitation $<1 \mathrm{~mm}$ & $80-90$ \\
\hline Sum of precipitation in the vegetation period & $300-350 \mathrm{~mm}$ \\
\hline Sum of precipitation in the winter period & $200-300 \mathrm{~mm}$ \\
\hline Number of days with snow cover & $40-50$ \\
\hline Number of cloudy days & $110-120$ \\
\hline Number of cloudless days & $50-60$ \\
\hline
\end{tabular}




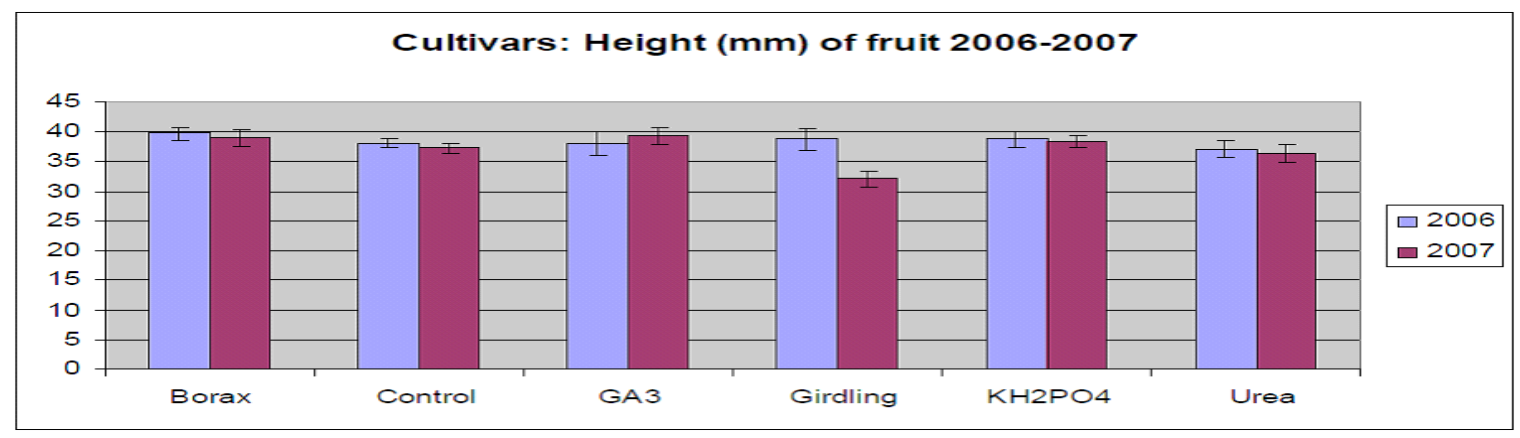

Fig. 1. Effect of different treatments on the height [mm] of fruit in Ziziphus jujuba Mill.

In Indian jujube, seedlings begin to bear fruit in the third or fourth year. In south - East Asia; it flowers with shoot growth in the wet season. As with Chinese jujube, the cultivars can be assigned to two groups based on anthesis time, those in which anthesis occur in the morning and those with anthesis in the afternoon. The stigma is receptive on the day of anthesis. The pollen is sticky and hence is not transferred by wind. In India, the honeybee and the house fly are the main pollinating insects, but many other insects are attracted to the flowers. The cultivars are self-incompatible, and some cultivar combinations are cross- incompatible. Only a small percentage of the flowers produces mature fruit, but this can be sufficient for a full crop [7].

\section{Pollination}

Generally, pollination is used mainly for breeding purpose. By pollinating the flowers on plants by hand, are assured a number of things: it assures pollination of the female flower and it will increase the likelihood of pollinating all segments of the female flower. Multi-segmented stigmas exist in the flowers of many plants. Chinese jujube are deciduous and can tolerate cold winters to -28 degrees F. They have a low chilling requirement allowing them to produce fruit in areas having mild winters. Long, hot summers are necessary to ripen good fruit crops. Flowers are small, approximately, 1/5 inch diameter, white, somewhat fragrant, and produced in large numbers in leaf axils. Flowering period extends over several months from late spring into summer [8]. Most jujube cultivars produce some fruit without cross pollination, but reports from California indicate yields are much higher when two or more different cultivars are planted together. Pollination is done by bees and flies.

\section{Fruit growth and development}

Immediately after fruit set, there is a very heavy fruit drop due to lack of ovule formation. The fruit development period varies from 108 to 180 days depending on cultivars and location, and shows a double sigmoid growth pattern.

As the fruit grows, there are increases in length, breath, weight, soluble solids, sugars and ascorbic acid and decreases in acidity, starch, phenolics and specific gravity [8].

\section{Methods}

This work is part of my PhD. research. The investigation on are being carried out at the Department of Pomology, Faculty of Horticulture in Lednice, Mendel University of Agriculture and Forestry in Brno, Czech Republic.

\section{Climatic characteristics}

According to Quitt's classification, Lednice belongs to the warm region T4 [19, Pp. 232-233]. Climatic characteristics are given in the table 2 .
The altitude of Lednice is approximately 170 meters above the sea level. Lednice enjoys the temperate climatic conditions prevailing in the south-eastern part of the Czech Republic, the south Moravia region. The average annual temperature in Lednice is $9.2^{\circ} \mathrm{C}$. In 2006 and 2007 the average annual temperature was $10{ }^{\circ} \mathrm{C}$ and $11.2{ }^{\circ} \mathrm{C}$ respectively. Average annual temperature during the vegetation period was $15.7^{\circ} \mathrm{C}$. In 2006 and 2007 the average temperature during the vegetation period was $17.2^{\circ} \mathrm{C}$ and $17.7^{\circ} \mathrm{C}$ respectively (Rožnovský and Litschmann 2008). The average annual temperature according to the Climate Atlas of Czechia is 9-10 ${ }^{\circ} \mathbf{C}[19$, Pp. 24-25]. Map is given in the figure below (fig. 1).

Average coolest month was January $-1.9{ }^{\circ} \mathrm{C}$. The coolest month in 2006 and 2007 was January $-5.8{ }^{\circ} \mathrm{C}$ and December $0.4{ }^{\circ} \mathrm{C}$ respectively. Average hottest month was July $19.1{ }^{\circ} \mathrm{C}$. The hottest month in 2006 and 2007 was July $23.5^{\circ} \mathrm{C}$ and $21.3{ }^{\circ} \mathrm{C}$ respectively. Length of the summer (average temperature above $15^{\circ} \mathrm{C}$ ) in 2006 and 2007 was 131 days and 119 days respectively. Number of summer days (average day temperature higher than $25^{\circ} \mathrm{C}$ ) in 2006 and 2007 was 14 and 11 respectively. In 2006 there were 277 days without frost (Rožnovský and Litschmann 2008).

The annual rain fall in Lednice is $480 \mathrm{~mm}$. In 2006 and 2007 the annual rain fall was $579.4 \mathrm{~mm}$ and $584.4 \mathrm{~mm}$ respectively. During vegetation the annual rainfall in 2006 and 2007 was $401.7 \mathrm{~mm}$ and $343.3 \mathrm{~mm}$ respectively (Rožnovský and Litschmann 2008). The average annual precipitation according to the Climate Atlas of Czechia is $450-500 \mathrm{~mm}$ [19, Pp. 68-69]. Map is given in the figure (fig. 2).

Fruit setting in Jujube

The aim of this research was conducted to improve fruit set using different types of treatments and to find out the best treatment on the basis of number of fruits and pomological traits. Fruit-set was improved using the following methods [6]:

1. Spraying on flowers during full blooming season (25\%-50\% flowers are open),

2. Girdling during blooming season (approximately $30 \%$ flowers are opening), main stem ring-girdling (removing the bark of 3-5 mm wide strip of bark, depending on the diameter of the tree) just like in apple tree. For the improvement of fruit set different types of treatments could be used. For the purpose of this research, six treatments were selected to improve pollination [6]). Twelve trees of the cultivar "Lang" were used for the trial.

Two plants were used for each treatment:

$$
\begin{array}{ll}
\text { - } & \text { Borax: } 0.3 \% \\
\text { - } & \text { Urea: } 0.5 \% \text {; } \\
\text { - } & \mathrm{KH}_{2} \mathrm{PO}_{4} 0.4 \%
\end{array}
$$




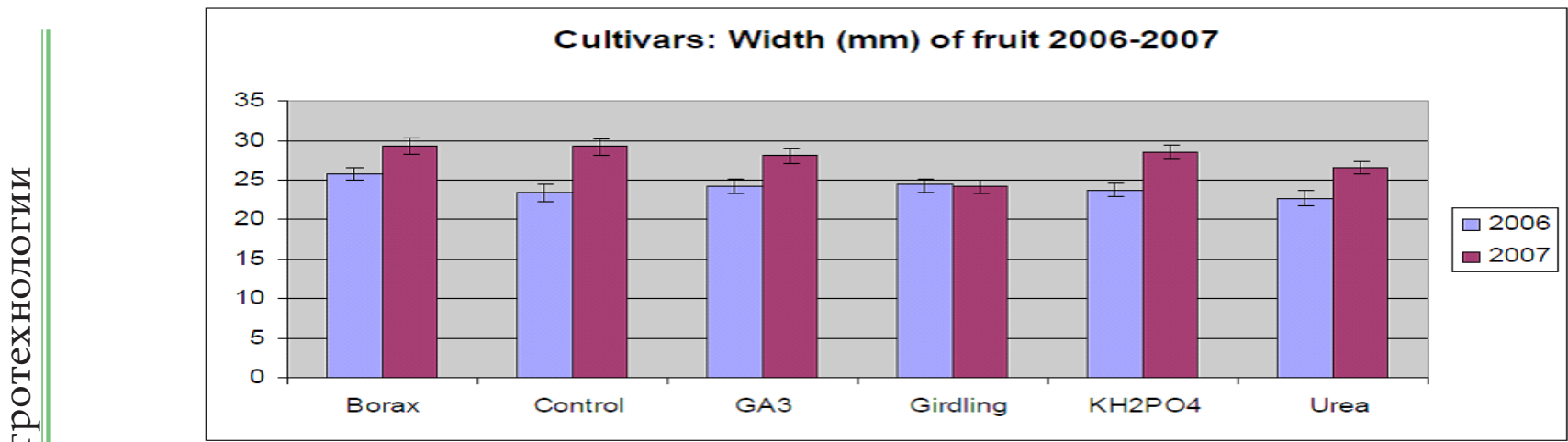

Fig. 2. Effect of different treatments on the width ( $\mathrm{mm}$ ) of fruit in Ziziphus jujuba Mill.

Table 3

Effect of different treatments on the weight [g] of fruit in seedlings of Ziziphus jujuba Mill.

\begin{tabular}{|l|c|c|c|c|}
\hline \multicolumn{1}{|c|}{ Treatment } & $\mathbf{2 0 0 6}$ & $\mathbf{1} / \mathbf{2}$ conf & $\mathbf{2 0 0 7}$ & $1 / 2$ conf \\
\hline Borax & 18.300 & 0.9373 & 19.6500 & 0.649121678 \\
\hline Control & 19.7000 & 0.7454 & 19.5000 & 0.492030551 \\
\hline Girding & 19.2500 & 0.6420 & 19.8000 & 0.517161772 \\
\hline $\mathrm{KH}_{2} \mathrm{PO}_{4}$ & 18.850 & 1.1492 & 20.0500 & 0.616325493 \\
\hline Urea & 18.7000 & 0.8736 & 19.1000 & 0.39886136 \\
\hline Average & 19.0 & 0.9 & 19.6 & 0.5 \\
\hline
\end{tabular}

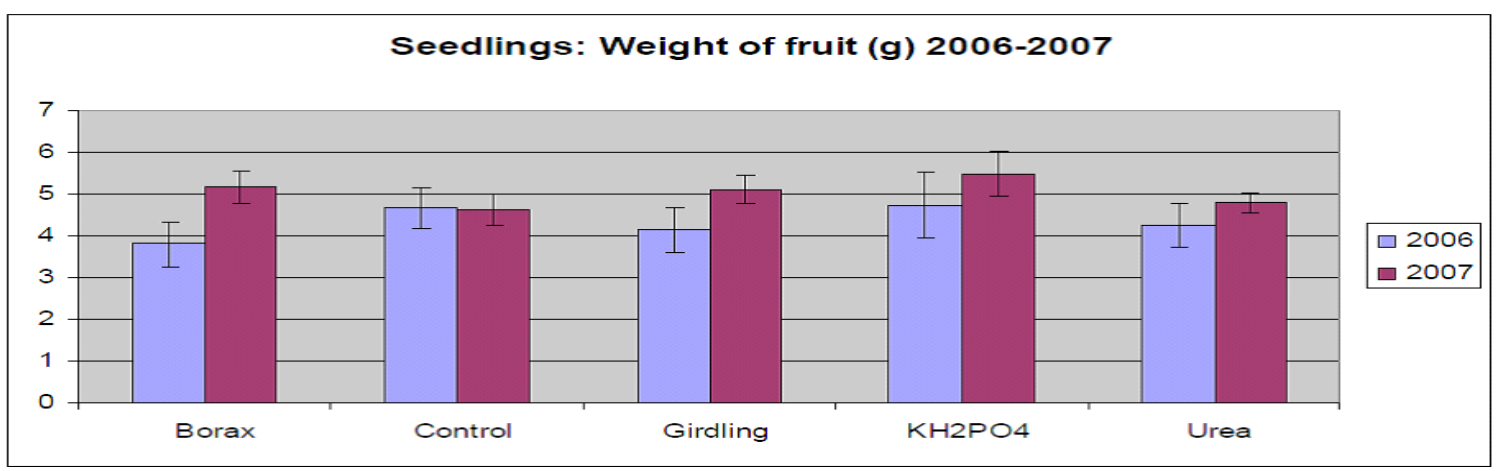

Fig. 3. Effect of different treatments on the weight [g] of fruit in seedlings of Ziziphus jujuba Mill.

- $\quad \mathrm{GA}_{3}: 5-10 \mathrm{ppm}($ or $\mathrm{mg} / \mathrm{L})$;

- Girdling;

- Control.

For the same trial in seedlings, five treatments were selected. Three trees were used for the treatments. Five branches on the tree were selected, each for different treatment:

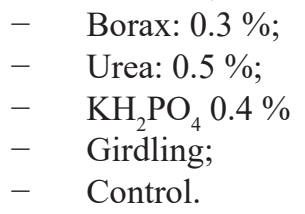

Treatments were sprayed on Jujube twice a year. First, when $25 \%$ flowers were open and again when $50 \%$ flowers were open. For evaluation of fruit setting there were counted flowers on the trees. Usually counting started from the first week of July till the last week of August.

Cultivars. In 2006, 100 flowers were counted per tree, two trees for each treatment. In 2007, 300 flowers were counted per tree (three branches, 100 flowers/branch), two trees for each treatment.

Seedlings. In 2006 and 2007 as well, 100 flowers were counted per branch, each branch with different treatment. Total yield was counted only from 2 plants, not from 3 as in the case of cultivars. In the case of Urea treatment, the branch of the third seedling was grafted. A pomological description based on shape, color, weight, thickness, height and width was made for each different treatment, twenty fruits were evaluated for each treatment.

\section{Fruit setting in cultivars}

For evaluation of fruit setting there were counted flowers on the trees (selected branches / treatment). The results from the year 2006 show that these treatments don't affect on shape, colour and height, in 2007 height was affected. Shape of fruit was oval in 2006 and also in 2007 was the same as well, regardless the treatment. Color was brown in 2006 and 2007 as well, regardless the treatment. Regarding number of fruits, there were statistically highly significance differences between treatments. There were no significance differences between Girdling, Borax, $\mathrm{KH}_{2} \mathrm{PO}_{4}$, and $\mathrm{GA}_{3}$. There were highly significance differences between Urea and Control. Results are given below.

The weight of fruit from the different treatments in 2006; Borax, Control, $\mathrm{GA}_{3}$, Girdling, $\mathrm{KH}_{2} \mathrm{PO}_{4}$ and Urea were $14.4 \mathrm{~g}, 11.8 \mathrm{~g}, 12.9 \mathrm{~g}, 13.6 \mathrm{~g}, 13.3 \mathrm{~g}$ and $8.8 \mathrm{~g}$ respectively. The average weight of fruit from the different treatments in 2007; Borax, Control, GA 3 , Girdling, $\mathrm{KH}_{2} \mathrm{PO}_{4}$ and Urea were $15.4 \mathrm{~g}, 15.2 \mathrm{~g}, 13.8 \mathrm{~g}, 8.9 \mathrm{~g}, 13.5 \mathrm{~g}$ and $12.1 \mathrm{~g}$ respectively. 


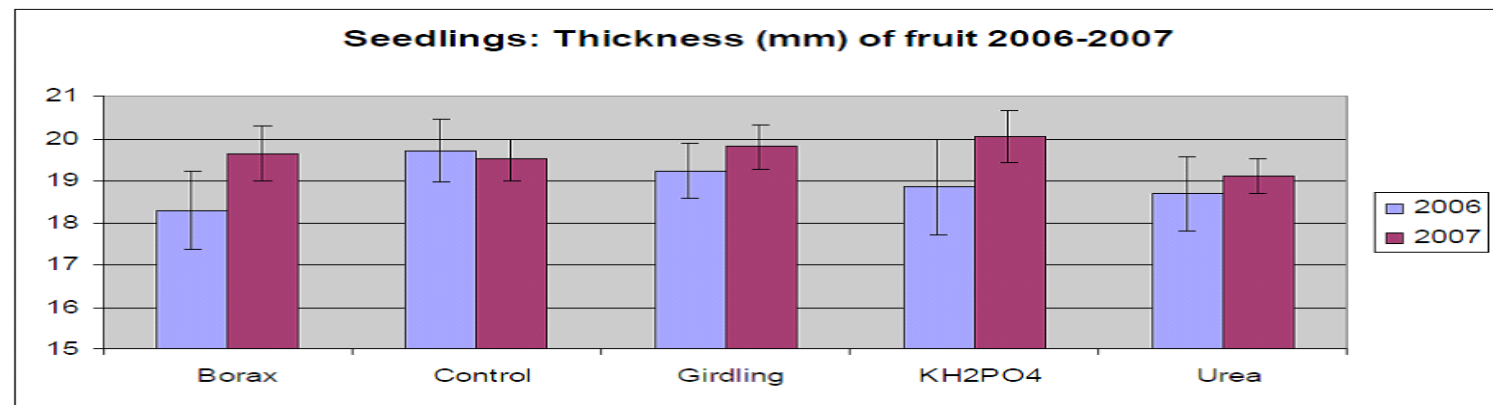

Fig. 4. Effect of different treatments on the thickness [mm] of fruit in seedlings of Ziziphus jujuba Mill.

Table 4

Effect of different treatments on the thickness [mm] of fruit in seedlings of Ziziphus jujuba Mill.

\begin{tabular}{|l|c|c|c|c|}
\hline \multicolumn{1}{|c|}{ Treatment } & $\mathbf{2 0 0 6}$ & $\mathbf{1} / 2$ conf & $\mathbf{2 0 0 7}$ & $1 / 2$ conf \\
\hline Borax & 3.8100 & 0.5383 & 5.1700 & 0.375364815 \\
\hline Control & 4.6650 & 0.4930 & 4.6200 & 0.368702564 \\
\hline Girding & 4.1350 & 0.5335 & 5.1100 & 0.349867646 \\
\hline $\mathrm{KH}_{2} \mathrm{PO}_{4}$ & 4.7350 & 0.7889 & 5.4950 & 0.525668447 \\
\hline Urea & 4.2750 & 0.5185 & 4.8000 & 0.23227654 \\
\hline Average & 4.3 & 0.6 & 5.00 & 0.4 \\
\hline
\end{tabular}

Treatments affect weight of fruit. In 2006 there were statistically highly significance differences between Urea and other treatments as well as between Control and Borax, in 2007 there were differences between Girdling and other treatments as well as between the Urea, $\mathrm{KH}_{2} \mathrm{PO}_{4}$ and Borax, Control. Results are given below (table 3, fig. 3 ).

The thickness of fruit from the different treatments in 2006: Borax, Control, GA, Girdling, $\mathrm{KH}_{2} \mathrm{PO}_{4}$ and Urea were $28.4 \mathrm{~mm}, 26.7 \mathrm{~mm}, 27.3 \mathrm{~mm}, 27.9 \mathrm{~mm}, 27.3 \mathrm{~mm}$ and $25.4 \mathrm{~mm}$ respectively. The average thickness of fruit from the different treatments in 2007; Borax, Control, $\mathrm{GA}_{3}$, Girdling, $\mathrm{KH}_{2} \mathrm{PO}_{4}$ and Urea were $26.4 \mathrm{~mm}, 26.2 \mathrm{~mm}, 25.6 \mathrm{~mm}, 22.2 \mathrm{~mm}, 25.9 \mathrm{~mm}$ and $24.2 \mathrm{~mm}$ respectively. Treatments affect thickness of fruit. In 2006 there were statistically highly significance differences between Urea and other four treatments, in 2007 between Girdling and other four treatments and Control. The difference between Urea and $\mathrm{GA}_{3}, \mathrm{KH}_{2} \mathrm{PO}_{4}$, Borax and Control was also statistically highly significant. Results are given below (table 4, fig. 4).

The height of fruit from the different treatments in 2007 Borax, Control, $\mathrm{GA}_{3}$, Girdling, $\mathrm{KH}_{2} \mathrm{PO}_{4}$ and Urea were $38.9 \mathrm{~mm}, 37.2 \mathrm{~mm}, 39.4 \mathrm{~mm}, 32.0 \mathrm{~mm}, 38.4 \mathrm{~mm}$ and $36.3 \mathrm{~mm}$ respectively. In 2007 treatments affect height of fruit. There were statistically highly significance differences between Girdling and other four treatments and Control. There were the differences between Urea and other three treatments $\left(\mathrm{KH}_{2} \mathrm{PO}_{4}\right.$, Borax and $\mathrm{GA}_{3}$ ) as well as between Control and $\mathrm{GA}_{3}$. Results are given below (table 5, fig. 5). In 2006 height was not affected by the treatments.

The width of fruit from the different treatments in 2006; Borax, Control, $\mathrm{GA}_{3}$, Girdling, $\mathrm{KH}_{2} \mathrm{PO}_{4}$ and Urea were $25.7 \mathrm{~mm}$, $23.4 \mathrm{~mm}, 24.2 \mathrm{~mm}, 24.4 \mathrm{~mm}, 23.7 \mathrm{~mm}$ and $22.6 \mathrm{~mm}$ respectively. The average width of fruit from the different treatments in 2007; Borax, Control, $\mathrm{GA}_{3}$, Girdling, $\mathrm{KH}_{2} \mathrm{PO}_{4}$ and Urea were $29.25 \mathrm{~mm}, 29.2 \mathrm{~mm}, 28.0 \mathrm{~mm}, 24.2 \mathrm{~mm}, 28.5 \mathrm{~mm}$ and $26.5 \mathrm{~mm}$ respectively. Treatments affect width of fruit. In 2006 there were statistically highly significance differences between Urea, Control, $\mathrm{KH}_{2} \mathrm{PO}_{4}$ and Borax. In 2007 there were differ- ences between Girdling and other four treatments and Control as well as between Urea and other three treatments $\left(\mathrm{KH}_{2} \mathrm{PO}_{4}\right.$, Borax and $\mathrm{GA}_{3}$ ) and Control. Results are given below (table 6 , fig. 6).

The total yield of fruit from the different treatments in 2006; Borax, Control, $\mathrm{GA}_{3}$, Girdling, $\mathrm{KH}_{2} \mathrm{PO} 4$ and Urea were $9500,1650,6216,3128,4340$ and $650 \mathrm{~g}$ respectively. The total yield of fruit from the different treatments in 2007; Borax, Control, $\mathrm{GA}_{3}$, Girdling, $\mathrm{KH}_{2} \mathrm{PO}_{4}$ and Urea were 8820, 8020, $17500,1600,4250$ and $4650 \mathrm{~g}$ respectively. Treatments also affect total yield of fruit in Ziziphus jujuba Mill. (table 7). Results showed that in 2006 Borax gave the best yield (9500 g) and Urea gave poor result ( $650 \mathrm{~g})$. In $2007 \mathrm{GA}_{3}$ gave the best result $(17500 \mathrm{~g})$ and Girdling gave the poor result (1600 g). Total yield from all the treatments was $25484 \mathrm{~g}$ in 2006 and $44840 \mathrm{~g}$ in 2007.

Two years evaluation of different treatments for fruit setting has given good results. On the basis of results it shows that Borax is the best treatment for fruit setting and pomological characteristics as well.

\section{Fruit setting in seedlings}

The results from the both years show that the treatments don't affect shape neither on color.

Shape of fruit was round in 2006 and also in 2007 was the same as well, regardless the treatment.

Color was golden-yellow in 2006 and 2007 as well, regardless the treatment.

Regarding number of fruits, in 2007, there is no significant difference between treatments. There is significant difference between Urea and Girdling, Urea and $\mathrm{KH}_{2} \mathrm{PO}_{4}$. There is no difference between Control and Borax certainly. Results are given below (table 8, fig. 7).

The weight of fruit from the different treatments in 2006: Borax, Control, Girdling, $\mathrm{KH}_{2} \mathrm{PO}_{4}$ and Urea were 3.8, 4.6, 4.1, 4.7, and $4.2 \mathrm{~g}$ respectively. The average weight of fruit from the different treatments in 2007; Borax, Control, Girdling, KH${ }_{2} \mathrm{PO}_{4}$ and Urea were 5.1, 4.6, 5.1, 5.4, and $4.8 \mathrm{~g}$ respectively. 


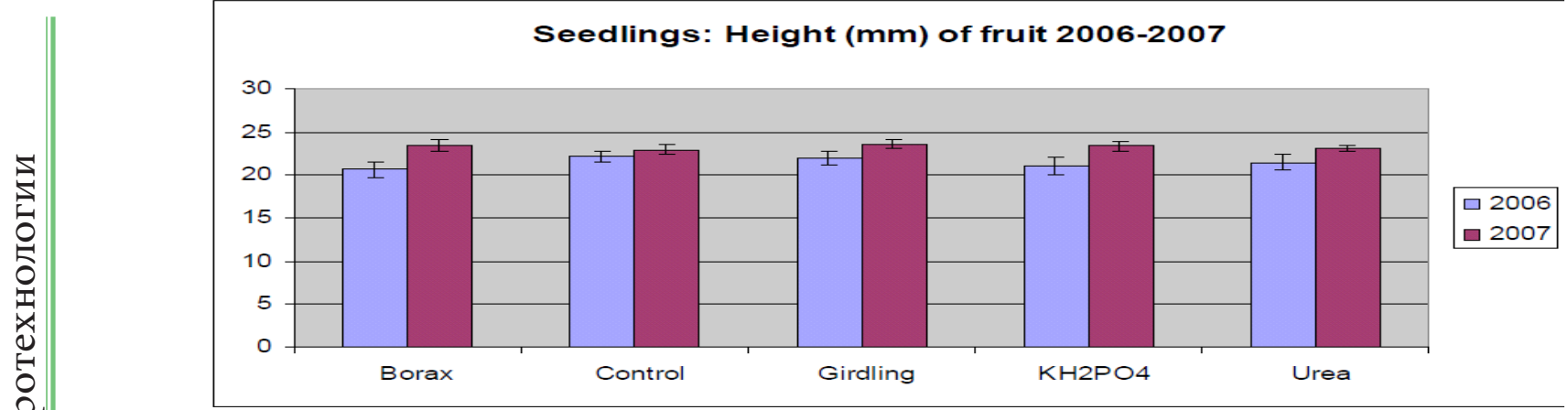

Fig. 5. Effect of different treatments on the height [mm] of fruit in seedlings of Ziziphus jujuba Mill.

Table 5

Effect of different treatments on the height $(\mathrm{mm})$ of fruit in seedlings of Ziziphus jujuba Mill.

\begin{tabular}{|l|c|c|c|c|}
\hline \multicolumn{1}{|c|}{ Treatment } & $\mathbf{2 0 0 6}$ & $\mathbf{1} / 2$ conf & $\mathbf{2 0 0 7}$ & $1 / 2$ conf \\
\hline Borax & 20.6500 & 0.9271 & 23.400 & 0.633391227 \\
\hline Control & 22.2000 & 0.5600 & 22.9500 & 0.57705771 \\
\hline Girding & 21.95000 & 0.7959 & 23.6000 & 0.5558400029 \\
\hline $\mathrm{KH}_{2} \mathrm{PO}_{4}$ & 21.05000 & 1.0240 & 23.3500 & 0.612573096 \\
\hline Urea & 21.4500 & 0.8916 & 23.1500 & 0.348745532 \\
\hline Average & 21.5 & 0.8 & 23.3 & 0.5 \\
\hline
\end{tabular}

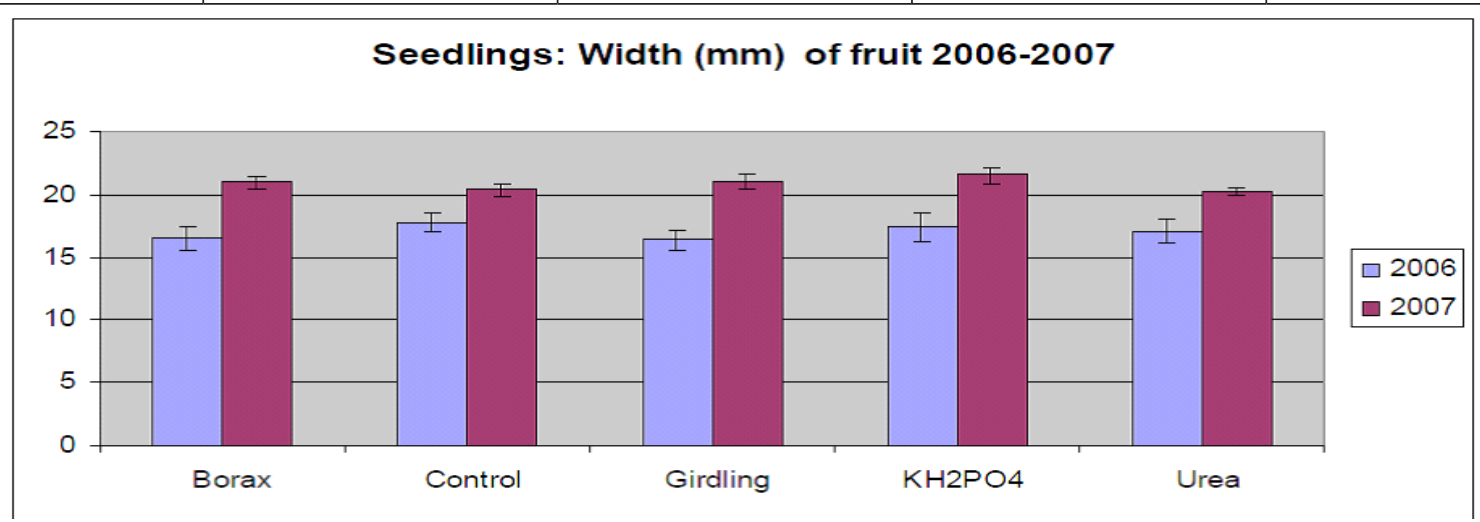

Fig. 6. Effect of different treatments on the width [mm] of fruit in seedlings of Ziziphus jujuba Mill.

Table 6 Effect of different treatments on the width [mm] of fruit in seedlings of Ziziphus jujuba Mill.

\begin{tabular}{|l|c|c|c|c|}
\hline \multicolumn{1}{|c|}{ Treatment } & $\mathbf{2 0 0 6}$ & $\mathbf{1} / 2$ conf & $\mathbf{2 0 0 7}$ & $1 / 2$ conf \\
\hline Borax & 16.5500 & 0.9540 & 20.9500 & 0.51436792 \\
\hline Control & 17.8000 & 0.7377 & 20.4000 & 0.512684096 \\
\hline Girding & 16.350 & 0.8355 & 21.0000 & 0.547481056 \\
\hline $\mathrm{KH}_{2} \mathrm{PO}_{4}$ & 17.400 & 1.1199 & 21.5500 & 0.687083272 \\
\hline Urea & 17.0500 & 0.9295 & 20.2500 & 0.3352962308 \\
\hline Average & 17.00 & 0.9 & 20.8 & 0.5 \\
\hline
\end{tabular}

Effect of different treatments on the total yield of fruit in seedlings of Ziziphus jujuba Mill.

\begin{tabular}{|l|c|c|c|c|c|}
\hline \multicolumn{1}{|c|}{ Treatment } & Total yield of fruit (g) & No. of fruits sm. Ch & $\begin{array}{c}\text { Average yield of fruit/ } \\
\text { tree (g) }\end{array}$ & $\begin{array}{c}\text { Avrage value } \\
\mathbf{2 0 0 6}+\mathbf{2 0 0 7}\end{array}$ \\
\hline Year & 2006 & 2007 & 2006 & 2007 & \\
\hline Borax & 1378 & 2250 & 460 & 750 & 605 \\
\hline Control & 1330 & 1800 & 443 & 600 & 521.5 \\
\hline Girding & 2674 & 3300 & 891 & 1100 & 995.5 \\
\hline $\mathrm{KH}_{2} \mathrm{PO}_{4}$ & 520 & 1300 & 173 & 433 & 303 \\
\hline Urea & 1190 & 2300 & 600 & 1150 & 875 \\
\hline Total & 7101 & 10950 & & & \\
\hline
\end{tabular}


Number of fruits (mean) in 2007 in cultivars

\begin{tabular}{|l|c|c|c|c|c|c|}
\hline \multicolumn{1}{|c|}{ Treatment } & No. of fruit mean & No. of fruits sm. Ch & $\begin{array}{c}\text { No. of fruits } \\
\mathbf{- 9 9 . 0 0 \%}\end{array}$ & $\begin{array}{c}\text { No. of fruits } \\
\mathbf{+ 9 9 . 0 0 \%}\end{array}$ & N & \\
\hline Girding & 0.33333 & 0.980167 & -2.36839 & 3.03505 & 6 & 2.70172 \\
\hline Borax & 0.83333 & 0.980167 & -1.86839 & 3.53505 & 6 & 2.70172 \\
\hline $\mathrm{KH}_{2} \mathrm{PO}_{4}$ & 2.50000 & 0.980167 & -0.20172 & 5.20172 & 6 & 2.70172 \\
\hline$G A 3$ & 4.00000 & 1.073719 & 1.04041 & 6.95959 & 6 & 2.95959 \\
\hline Urea & 10.00000 & 0.980167 & 7.29828 & 12.70172 & 6 & 2.70172 \\
\hline Control & 8.50000 & 0.980167 & 5.79828 & 11.20172 & 6 & 2.70172 \\
\hline
\end{tabular}

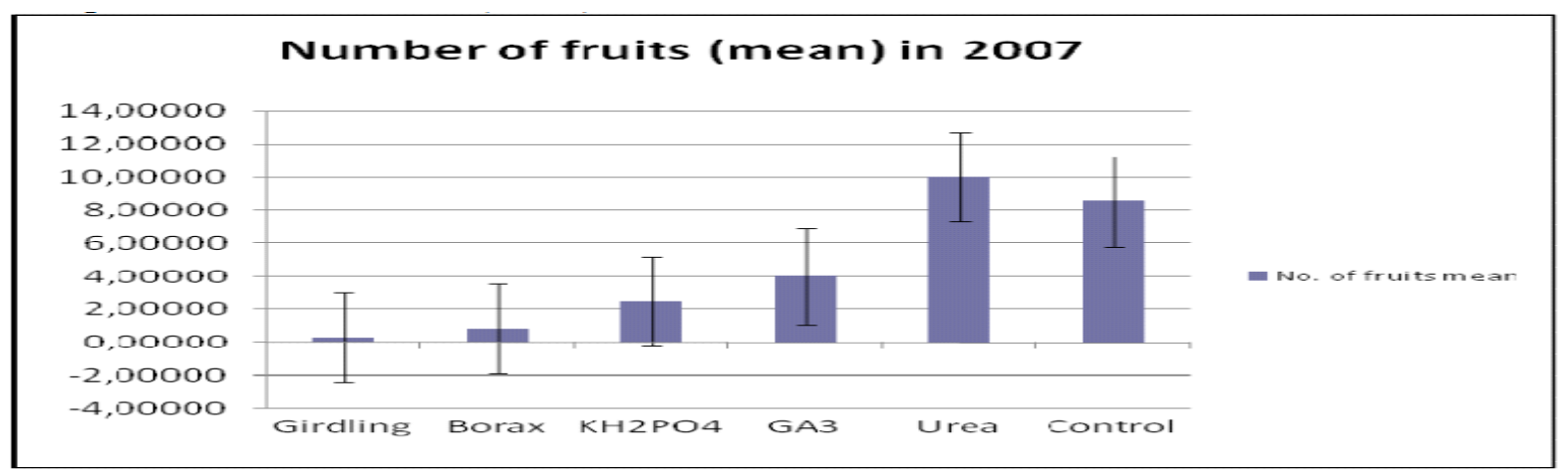

Fig. 7. Number of fruits (mean) in 2007 in cultivars

Treatments affect weight of fruit. In 2006 record observation showed that there were no statistically significant differences among the treatments. In 2007 there were statistically significant differences between $\mathrm{KH}_{2} \mathrm{PO}_{4}$ and control as well as Urea. Results are given below (table 3, fig. 3).

The thickness of fruit from the different treatments in 2006: Borax, Control, Girdling, $\mathrm{KH}_{2} \mathrm{PO}_{4}$ and Urea were 18.3, $19.7,19.2,18.8$, and $18.7 \mathrm{~mm}$ respectively. The average thickness of fruit from the different treatments in 2007: Borax, Control, Girdling, $\mathrm{KH}_{2} \mathrm{PO}_{4}$ and Urea were 19.6, 19.5, 19.8, 20.0, and $19.1 \mathrm{~mm}$ respectively. Treatments affect thickness of fruit. Record observation shows that there were no statistically significant differences among the treatments in 2006 neither in 2007. Results are given below (table 4, fig. 4 8).

The height of fruit from the different treatments in 2006; Borax, Control, Girdling, $\mathrm{KH}_{2} \mathrm{PO}_{4}$ and Urea were 20.6, 22.2, $21.9,21.0$, and $21.4 \mathrm{~mm}$ respectively. The average height of fruit from the different treatments in 2007; Borax, Control, Girdling, $\mathrm{KH}_{2} \mathrm{PO}_{4}$ and Urea were 23.4, 22.9, 23.6, 23.3, and $23.1 \mathrm{~mm}$ respectively. Treatments affect height of fruit. Record observation shows that there were no statistically significant differences among the treatments in 2006 neither in 2007. Results are given below (table 5, fig. 5).

The width of fruit from the different treatments in 2006: Borax, Control, Girdling, $\mathrm{KH}_{2} \mathrm{PO}_{4}$ and Urea were 16.5, 17.8, $16.3,17.4$, and $17.0 \mathrm{~mm}$ respectively. The average width of fruit from the different treatments in 2007: Borax, Control, Girdling, $\mathrm{KH}_{2} \mathrm{PO}_{4}$ and Urea were 20.9, 20.4, 21.0, 21.5, and $20.0 \mathrm{~mm}$ respectively. Treatments affect width of fruit. Record observation shows that there were no statistically significant differences among the treatments in 2006. In 2007 there were statistically significance differences between $\mathrm{KH}_{2} \mathrm{PO}_{4}$ and control as well as Urea. Results are given below (table 6, fig. 6).

The total yield of fruit from the different treatments in 2006: Borax, Control, Girdling, $\mathrm{KH}_{2} \mathrm{PO}_{4}$ and Urea were 1378 , 1330, 2674, 520 and $1199 \mathrm{~g}$ respectively. The total yield of fruit from the different treatments in 2007: Borax, Control Girdling, $\mathrm{KH}_{2} \mathrm{PO}_{4}$ and Urea were 2250, 1800, 3300, 1300 and $2300 \mathrm{~g}$ respectively. Treatments also affect total yield of fruit in seedling of Ziziphus jujuba Mill. Results showed that in 2006 Girdling gave the best yield (2674 g) and $\mathrm{KH}_{2} \mathrm{PO}_{4}$ gave poor result (520 g). In 2007 Girdling gave the best result (3300 g) and $\mathrm{KH}_{2} \mathrm{PO}_{4}$ gave the poor result $(1300 \mathrm{~g})$. Total yield from all the treatments was $7101 \mathrm{~g}$ in 2006 and $10950 \mathrm{~g}$ in 2007.

Two years evaluation of different treatments for fruit setting has not given satisfactory results. Spraying with different treatments did not affect fruit-setting and pomological characteristics as well, in a larger scale.

In the case of Urea treatment, the yield was measured from the two seedlings, not from the third one. The particular Urea branch of the third seedling was grafted and yield from this effect was much higher than from the other branches.

\section{Fruit setting in jujube}

For the improvement of fruit set, six treatments were selected in cultivars (Borax, Urea, $\mathrm{KH}_{2} \mathrm{PO}_{4}, \mathrm{GA}_{3}$, Girdling, and Control) and five treatments in seedlings, where $\mathrm{GA}_{3}$ was not used. In seedlings, 100 flowers were counted per branch; each branch has got one treatment. In the case of seedlings, the small size of trees and limited number of branches doesn't allow the use of more replications like in the case of cultivars. A pomological description based on shape, colour, weight, thickness, height and width was made for each different treatment, twenty fruits were evaluated for each treatment in seedling and cultivars as well.

\section{Fruit setting in cultivars}

Under natural conditions, fruit set in jujube is low, usually less than $1 \%$ (Singh 1995). It is very important to improve the fruit set in Chinese jujube production. Singh (1995) has reported that fruit set of Chinese jujube can be improved by spraying 10-20 ppm GA 3 3-4 times starting at full-bloom. In our research, $\mathrm{GA}_{3}$ 5-10 ppm was sprayed for improving the fruit set, and the spraying of this treatment was not so success- 
ful like spraying of Borax. Borax gave the best result in the case of cultivars in almost all pomological characteristics, in both years.

On the other hand, Urea and Girdling gave poor results in 2006 and 2007. Borax also gave the best yield in 2006; in 2007 $\mathrm{GA}_{3}$ gave the best result. From the above mentioned reasons and results, we recommend using of Borax for improvement of fruit setting in jujube is cheaper than $\mathrm{GA}_{3}$ and the frequency of Borax to get number of fruits in jujube is much higher than $\mathrm{GA}_{3}$. The exceptional value of height shows that the average value in 2007 was higher in $\mathrm{GA}_{3}$. Random selection of fruits caused the irregularities in results in the case of height. To avoid the same in the future would be better to choose more fruits for verification.

\section{Fruit setting in seedlings}

On the basis of results from both years showed that the treatments don't affect shape or colour, other pomological characteristics were affected.

The weight of fruit was the highest in $\mathrm{KH}_{2} \mathrm{PO}_{4}$ in both years. The lowest value of weight was in the case of Borax in 2006 and Control in 2007. The thickness of fruit was the highest in Control in 2006 and in $\mathrm{KH}_{2} \mathrm{PO}_{4}$ in 2007. The lowest value of thickness was in the case of Borax in 2006 and Urea in 2007. The height of fruit was the highest in Control in 2006 and in Girdling in 2007. The lowest value of height was in the case of Borax in 2006 and Control in 2007. The width of fruit was the highest in Control in 2006 and in $\mathrm{KH}_{2} \mathrm{PO}_{4}$ in
$2007(21.5 \mathrm{~mm})$. The lowest value of width was in the case of Girdling $(16.3 \mathrm{~mm})$ in 2006 and Urea $(20.0 \mathrm{~mm})$ in 2007.

Regarding the size of fruit, Control gave the best results. From this reason we can conclude that in the case of seedlings, treatments don't affect pomological characteristics as in the case of cultivar. On the other side, treatments affect total yield of fruit, which reached the highest value in Girdling in 2006 and 2007 as well. $\mathrm{KH}_{2} \mathrm{PO}_{4}$ gave poor results in both the years.

The probable reason for non-significant effect of different treatment on size and colour in jujube may be attributed to the adverse climatic conditions for the seedlings which might have led to improper colour development and under sized fruit.

\section{Discussion and Conclusion}

\section{Fruit setting in cultivars}

Studies conducted on effect of different treatments on fruit setting in jujube shows that Borax is the best treatment for fruit setting and pomological characteristics as well. Spraying of Borax showed that average numbers of fruits were higher than the other treatments, average values of height, weight, width and thickness were also higher than the other treatments. On the other hand Urea and Girdling gave poor results in 2006 and 2007 respectively.

\section{Fruit setting in seedlings}

On the basis of result it can be concluded that in the most cases $\mathrm{KH}_{2} \mathrm{PO}_{4}$ gave satisfactory result. In general, spraying with different treatments did not affect fruit-setting and pomological characteristics as well, in a larger scale.

\section{References}

1. Choi S. H., Ahn J. B., Kozukue N., Levin C. E., Friedman M. Distribution of free amino acids, flavonoids, total phenolics, and antioxidative activities of jujube (Ziziphus jujuba) fruits and seeds harvested from plants grown in Korea // Journal of Agricultural \& Food Chemistry. 2011. Vol. 59. No. 12. Pp. 6594-6604.

2. Chen F., Liu K., Zhang J., et al. Target identification method of lingwu dates based on bp neural net-work. The Open Automation and Control Systems Journal. 2014. Vol. 6. No. 1. Pp. 670-675.

3. Cossio F., Bassi G. Field performance of six chinese jujube cultivars introduced and tested in northern Italy // Acta Hortic. 2013. No. 993. Pp. 21-28.

4. Fan X., Zhang H., Li C., et al. The development of the pneumatic cutting machine used in a dwarf dense planting jujube garden // Journal of Shandong Agricultural University. 2014. No. 45. Pp. 694-697.

5. Ge Y., Fang J., Wang S., et al. Status of mechanized pruning techniques zaoyuan close planting dwarf. J. Agric. Mech. Res. 2013. No. 35. Pp. 249-252.

6. Hao-Yuan S. Discussion about Ziziphus sp. Personal communication. Institute of Forestry and Pomology, Academy of Agriculture and Forestry Sciences, Beijing, China, 2005.

7. Janick J. The Encyclopedia of Fruits \& Nuts. Oxfordshire. Cambridge: CAB International, 2008. Pp. 615-619.

8. Schalau J. The Chinese jujube // Agriculture and natural resources. University of Arizona Co-operative Extension, 2011.

9. Krska B., Mishra S. Sensory evaluation of different products of Ziziphus jujuba Mill. // Acta Horticulturae. 2008. No. 840. Pp. 557-562.

10. Koetter U., Barrett M., Lacher S., et al. Interactions of magnolia and ziziphus extracts with selected central nervous system receptors // Journal of Ethnopharmacology. 2009. No. 124. Pp. 421-425.

11. Li R., Peng J., Sun S. P., Al-Mallahi A., Fu L. S. Determination of selected physical and mechanical properties of chineese jujube fruit and seed. Agricultural engineering international. Canadian Institute for Jewish Research Journal. 2014. Vol. 18. No. 3. Pp. 294-300.

12. Liu M. Chinese jujube: botany and horticulture. Horticultural Reviews. 2010. No. 32. Pp. 229-298.

13. Mahajan R., Chopda M. Phyto-Pharmacology of Ziziphus jujuba Mill. - A plant review // Pharmacognosy Reviews. 2009. Vol. 3. No. 6. Pp. 320-329.

14. Siriamornpun S., Weerapreeyakul N., Barusrux S. Bioactive compounds and health implications are better for green jujube fruit than for ripe fruit // Journal of Functional Foods. 2015. No. 12. Pp. 246-255.

15. Tang Z., Meng X., Shen C., et al. Design and experimental investigation of mechanical vibration tree fruits and nuts harvester // J. Agric. Mech. Res. 2010. No. 32. Pp. 65-69. 


\section{Agrarian Bulletin of the Urals No. 06 (197), 2020}

16. Williams J. T. Taxonomy and Nomenclature. Climate and Ecology. Agronomy // Azam-Ali S., E. Bonkoungou, et al. Ber and other jujubes. Southampton: Southampton Centre for Underutilised Crops, 2006.

17. Yao S. Past, Present, and Future of Jujubes - Chinese Dates in the United States // HortScience. 2013. Vol. 48. No. 6. Pp. 672-680.

18. Xiaopeng Li, Yupeng Li, Zhong Zhang, Xingang Li. Influences of environmental factors on leaf morphology of Chineese jujubes. College of forestry, northeast university, Yangling, Shaanxi, China. 2015.

19. Tolasz R., Míková T., Valeriánová A., Voženílek V. (eds). Climatic Atlas of Czechia. ČHMÚ, Prague, 2007.256 p. (In Czech.)

\section{Authors' information:}

Saket Mishra ${ }^{1}, \mathrm{PhD}$, assistant professor, ORCID 0000-0001-8289-0454; mishrasaket1@gmail.com

Mithun Tarafdar ${ }^{1}, \mathrm{PhD}$, assistant professor, ORCID 0000-0003-0418-3994

Ravi Kumar Singh ${ }^{1}$, PhD, assistant professor, ORCID 0000-0002-1016-7192

${ }^{1}$ Department of Horticulture, Faculty of Agriculture, Sam Higginbottom University of Agriculture, Technology and Sciences, Allahabad, India 